\title{
IDENTIDADE COMO ALEGORIA EM SAMUEL RAWET E MOACYR SCLIAR: UM ENSAIO SOBRE A LITERATURA JUDAICA DO SÉCULO XX
}

\section{IDENTITY AS ALLEGORY IN SAMUEL RAWET AND MOACYR SCLIAR: AN ESSAY ON TWENTIETH-CENTURY JEWISH LITERATURE}

Dennis Sobolev*

\section{Resumo}

Este ensaio tem dois objetivos mutuamente relacionados. Num nível mais teórico, que aborda a problemática geral dos estudos literários judaicos modernos, tem como objetivo destacar e avaliar um conjunto de suposições a partir das quais normalmente se aborda, analisa e interpreta as obras de autores de literatura judaica moderna. Este ensaio começa com uma discussão breve a respeito do uso destes conceitos a categorias interpretativas, tais como centro e periferia, autônomo e híbrido, monolinguístico e plurilinguístico, assim como uma série de dicotomias relacionadas. Também discute dois grandes modelos que são usados na conceptualização das literaturas judaicas modernas: o "essencialista" e o "de contingência". Em oposição às categorias taxonômicas mencionadas acima, assim como em oposição aos modelos representativos, este ensaio sugere que as obras de literatura judaica moderna podem ser melhor compreendidas por meio do modelo de "poéticas regionais" judaicas, uma vez que tais poéticas são estruturadas por “dominantes culturais”. Levando em consideração estas questões e estes problemas de caráter relativamente genérico, mas ainda assim focalizando um destes dominantes culturais - o modo alegórico de escrita literária - o ensaio analisa as representações de identidade nas obras de Samuel Rawet e Moacyr Scliar. Uma vez que o foco sobre o problema da identidade judaica foi

\footnotetext{
* Professor do Departamento de Literatura Hebraica e Comparada da Univerdade de Haifa (Israel). E-mail: $<$ dennissobolev@hotmail.com>
} 
repetidas vezes representado como a característica central na definição da categoria literatura judaica, o problema da identidade torna-se significativo num nível teórico também. A análise realizada neste ensaio mostra que tanto nas obras de Samuel Rawet quanto nas de Moacyr Scliar as representações da identidade judaica passam por um processo de gradativa alegorização, que redefine o problema da identidade como um ponto de partida para uma vasta gama de questões, problemas e ambivalências fenomenológicos, epistemológicos, éticos e sociais. Ao mesmo tempo, se em Rawet a alegorização é dominada pela melancolia, em Scliar ela é estruturada por discrepâncias textuais multifacetadas, assim como por modos de representação picarescos e irônicos. A seção final deste ensaio traz a discussõ de volta para uma perspectiva literária mais ampla e sugere que os processos de alegorização do problema da identidade judaica são também característicos de outras "poéticas regionais" judaicas, que se encontram além dos limites da literatura judaico-brasileira. Além disto, esta parece ser uma das mais significativas e literariamente sugestivas e eficientes características das literaturas judaicas do século XX de um modo geral.

Palavras-chave: problemas de literaturas judaicas, civilização judaica, modelo essencialista, modelo de contingência

\begin{abstract}
This essay has two mutually related goals. At a more theoretically oriented level of the general problematics of modern Jewish literary studies, it aims to foreground and reappraise several assumptions upon which the works of modern Jewish writers are usually approached, analyzed and interpreted. The essay begins with a brief discussion of the use of such concepts and interpretative categories as center and periphery, autonomous and hybridic, monolingual and multilingual, as well as a number of related dichotomies. It also addresses the two major models which are used for conceptualizing modern Jewish literatures: 'the essentialist' and 'the contingent' ones. In contrast to the above taxonomic categories, as well as the both opposed representative models, this essay suggests that modern Jewish literary works can better be understood and analyzed through the model of Jewish 'regional poetics,' as these poetics are structured by 'cultural dominants.' With an eye on these relatively general questions and problems, yet focusing on one of such cultural dominants - the allegorical mode of literary
\end{abstract}


writing - the essay analyzes the figurations of identity in the works of Samuel Rawet and Moacyr Scliar. As the focus on the problem of Jewish identity has repeatedly been represented as the pivotal characteristic that defines Jewish literary works as a category, the problem of identity is significant at the theoretical level as well. The analysis carried out in this essay shows that both in Samuel Rawet and Moacyr Scliar the representation of Jewish identity undergo a gradual process of allegorization, which redefines the very problem of identity as a figure for a broad range of ontological, phenomenological, epistemological, ethical and social problems, questions and ambivalences. At the same time, whereas in Rawet allegoresis is dominated by the melancholic, in Scliar it is structured by multi-layered textual discrepancies, as well as the picaresque and the ironic modes of representation, The concluding section of the essay brings this discussion back to a broader literary perspective. It suggests that concordant processes of the allegorization of the problem of Jewish identity characterize other Jewish 'regional poetics,' beyond the limits of Brazilian Jewish literature; moreover, this seems to be one of the most significant, as well as literary efficient and suggestive, characteristics of twentieth-century Jewish literatures, in general. Keywords: problem of Jewish literatures, Jewish civilization, the essentialist model, the contingent model 
This essay has a double-faceted goal. In a more narrow sense, it focuses on various aspects of the figurations of identity in the works of Samuel Rawet and Moacyr Scliar, as well as their metaphorization of the very problem of identity. At the same time, I address this analysis with more general questions in mind, which relate to the various assumptions and contexts upon which the works of modern Jewish writers are usually approached, analyzed and interpreted. Correspondingly, it is with a discussion of these contexts, questions and assumptions that I would like to begin. This introductory discussion will render the analysis that follows more meaningful at two different, though interrelated, levels: as an analysis of what seems to me a significant dimension in the works of two brilliant Jewish writers and, simultaneously, as a case study, which aims to foreground some of the major theoretical questions and problems of modern Jewish literary studies. Both this introduction and the following discussion of Rawet and Scliar will underscore the necessity of reassessing some of the major assumptions and frameworks of these studies, and will propound alternative paths for the exploration and re-conceptualization of their recurrent questions.

The first of these major "contextual" questions relates to our general conceptualization of Jewish civilization. As this civilization has usually been considered as existing in time, rather than in space, spatial metaphors were found especially useful for its re-conceptualization, for both imaginative and analytical purposes. Jewish civilization was imagined as a huge tree, rooted somewhere in early Biblical times, thickening around the times of the Second Temple, and later being divided into numberless unequal diasporic branches. Some of these branches were viewed as central to this imaginary spatial structure, while others had to be understood in relation to these imaginary centers. Among the assumed centers of this literalized spatial metaphor, the Sages of Babylon, the "Golden Age" of Jewish Spain, the Hassidic culture of Poland and the Russian Empire, and the United States post-Second World War have been habitually mentioned; the further from one of these centers a given phenomenon is, the more it was imagined as marginal, impure, mixed, hybridic, "the frontier" (Gilman 2003 1-15) or simply foreign. As this narrative goes, the primordial and, so to speak, prelapsarian unity of Jewish civilization has been restored in the State of Israel which, in this imaginary spatial sense, becomes the ultimate realization of a long chain of incomplete historical realizations of the various essences of Jewish culture. Correspondingly, according to this line of thought, the study of Jewish civilization had to follow 
both the historical logic of this division and unification, and the spatial logic of the centerperiphery model" (Gilman 2003 2), imposed on almost any period of Jewish cultural history when studied synchronically.

Probably no period has suffered more from the imposition of this metaphorical spatial imagination on actual cultural processes than twentieth-century Jewish culture. The yeshuv and the State of Israel were assumed not only to be one of these consequently changing centers, but the very center of these centers - the restoration of imaginary unity that existed before the Babylonian division into the language and cultures of the Jewish diaspora. Correspondingly, for a period of time it was assumed that almost any phenomena belonging to Jewish culture had to be studied in relation to this process of "national Renaissance" and the restoration of this primordial cultural center on the basis of the culture of Jewish Enlightenment in German-speaking countries and the Yiddish culture of the Pale of Settlement. In terms of practical cultural analysis, this position entailed the imaginary marginalization of a large number of Jewish communities - both large and small - so far as they did not fit this supposedly mainstream narrative. In addition, as even serious analyses of twentieth-century Jewish writers and philosophers frequently get bogged down in the discussions of the question of what is "really Jewish," these imaginary centers - be they the Jewish culture of the Western parts of the Russian Empire, Jewish-American or contemporary Israeli cultures - also function as criteria for the selection and delimitation of the object of study. The Jewish communities of South America, including those of Brazil and Argentina (Feierstein 2012 559-562) - like the three million Jewish communities of the Soviet Union after the Second World War, like those of Italy and the Balkan countries, or the diverse Jewish communities in the Islamic world - seem to be among those that were radically marginalized by this spatialization of historical memory and imagination.

The Modern Jewish Canon by Ruth R. Wisse (2000) probably realized this conception in its most impressive, convincing and broad form, tracing Jewish literary history from Sholem Aleichem (2000 31-64) to Israeli literature (2000 323-348), through the discussion of a few early Hebrew, Jewish-German and Jewish-Russian authors. However, by the time Wisse's book was published, the cultural continuity her study seems to imply was already being questioned and frequently denied; scholars have been even more critical towards any attempt to create an essentialist version of Jewish poetics (Wirth-Nesher 1994 3-12). Over the course of the last two 
decades, a significant number of objections to this linear or single-centered conceptualization of Jewish culture - or modern Jewish literary history - have been articulated; as it happens, some of these objections were more convincing, others less. Although their discussion must remain beyond the scope of this essay, it is important to mention some of them, as these objections bear directly upon the discussion of the literary works written in the languages that are still habitually labeled as "non-Jewish." As David Biale stresses in his introduction to what is still one of the most encompassing pictures of Jewish cultural developments since Biblical times, in its entirety this cultural world is too rich, too diverse and too heterogeneous for any cultural essence or single cultural continuity to be ascribed to it (Biale 2002 xii-xxxiii). Throughout almost its entire history, Jewish culture was open and often hybridic, as it developed through constant and deep interaction with the surrounding cultures: from the Babylonian, Hellenistic, Persian and Classical Arabic cultures to Modern European and American ones. Correspondingly, many of the important Jewish writers and thinkers were bi-, tri- or even multi-lingual; the Jewish cultural world is more accurately described as essentially polyphonic (Harshav 2007 23-40, Miron 2010 278-302, Weiss, Katsman and Kotlerman 2013 vii). In all these senses, the monolingual culture of the contemporary State of Israel as a modern nation state is rather an exception from earlier cultural developments (Miron 2010 20-21), even though there are many other elements of Jewish cultural traditions whose fuller realization the State of Israel has gradually made possible.

Given this situation, there emerges the question of an empirically adequate analytical framework for the analysis and conceptualization of Jewish literary works, or cultural developments, in general. Probably one of the most radical positions was expressed by Dan Miron in a recent book (2010) which, to a considerable extent, summarizes his enormous life's work on Jewish literary texts in modern times. Sometimes engaging in a direct debate with Wisse's conceptualization of the continuity of "the Jewish canon," Miron insists that the assumption of cultural "continuity" must be replaced with the concept of "contiguity" (Miron 2010 3-19) - and, correspondingly, with the analyses of local similarities and cultural encounters, whose non-linear and intricate network eventually forms the Jewish cultural world.

The main theoretical problem this position entails is that of the very object of study. Indeed, under close scrutiny, any given cultural phenomenon can be found similar to almost any other - in this or that sense; by the same token, at least in principle, almost any set of cultural phenomena 
may be represented as a decentered network of local similarities. This problem was not unknown to the earlier scholars of Jewish culture. Thus, although Biale chose the plural form for the title ("Cultures of the Jews") of his encyclopedic collection of essays, he also insisted that these "cultures" draw upon a common cultural heritage (the Bible and Rabbinic literature above all), which links them to each other (Biale 2002 xxiv). Addressing the same problem in the introduction to the most recent volume of a comparable size, richness and diversity, Hillel Weiss suggested that Jewish literature can roughly be conceptualized as reflecting and articulating the experiences of "the Jewish people" in different counties and throughout centuries; he proceeded to propound some common denominators of these literary reflections (Weiss 2013 4-6). Predictably, Weiss chose Miron as one of his main theoretical opponents (Weiss 2013 8). One can notice, however, that Weiss's answer to Miron's anti-essentialism assumes another entity that is conceptualized in relatively essentialist terms: "the Jewish people" or "the Jews" in Biale's more cautious wording. This conceptualization, in turn, entails the question of whether one can justifiably speak of "the Jewish people," with reference to the periods that precede the emergence of the contemporary meaning of the term "people" in the discourse of late Enlightenment and Romanticism. This conceptualization may also entail a large number of further questions concerning the assumed foundation of the cultural existence of "people" as a unity. One may ask, for example, whether a "people" is, in Benedict Anderson's terms, an "imaginary community," or, conversely, whether its social and cultural existence is based on genetic foundations, psychological similarities, a common culture or ethnic origins. All these questions have been repeatedly debated, many of them seem to be poorly asked, and almost no literary scholar has the expertise needed to deal with them in a scholarly adequate manner.

In response to this essentialist / anti-essentialist dilemma, and although I was glad to contribute an essay to the above-mentioned collection, I would like to reformulate my earlier "midway" position (Sobolev 2008 163-228). As it seems, this position makes it possible to avoid the dangers of extreme fragmentation and the potential loss of the object of study, on the one hand, without losing the grounds of empirical literary analysis, on the other. This position can be redefined as the necessity of examining Jewish "regional poetics." By "region," I mean not a physical or geographical space, but rather a group of literary texts, which are related to each other through a network of significant similarities, and which were written in relatively similar cultural 
and historical conditions. If a given group of texts indeed forms such a literary "region, " in examining these texts the scholar will notice that they possess a number of recurrent elements. Significantly, these elements are much more than just occasional points of contact and proximity, yet they are not obligatory structural characteristics either. To use Althusser's term in a slightly different sense, these non-obligatory yet recurrent elements may be called "cultural dominants" of "literary regions." In turn, the scholar may relate these cultural dominants, which are usually mutually connected, to cultural and historical conditions - as, for example, Lucien Goldmann does in The Hidden God, as well as his many followers. Employed in this manner, the metaphor of "region" not only conforms with the above-mentioned tradition of the metaphorical spatialization of Jewish cultural history, while introducing necessary corrections to its unwarranted implications, but seems to also be concordant to Blanchot's "space of literature" or the contemporary descriptions of the "the world republic of literature" (Casanova 1999).

From this point of view, relating Kafka to Hermann Broch, Benjamin or even Freud usually makes more empirical sense than searching in their works for the timeless essences of Jewish culture or comparing each of them separately to the Rabbinic writings of the first half of the first millennium. By the same token, in relating twentieth-century German Jewish writers to Russian Jewish writers or Brazilian Jewish writers or even North American Jewish writers, the scholar may reveal more significant similarities than by comparing either of them to the Midrash, the "golden age" of Hebrew poetry in Spain or contemporary Israeli fiction, which have been created in different historical and cultural circumstances. It is also in this sense of belonging to a similar or "neighboring" cultural "region" that Kafka or Benjamin, Mandestam or Celan may better serve the comparative understanding of Rawet and Scliar than the Tosefta or even Sholem Aleichem. In addition, as a given writer may belong to several cultural regions, such conceptualization may also help to avoid the radical and, as it seems, misleading dichotomies of belonging to Jewish/non-Jewish cultures. Finally, one should not be afraid of heuristic and tentative elements that are implied by this search for the cultural dominants of regional poetics - be they Jewish or not. Like a traveler who leaves the mountains for the plains and then suddenly understands that he has moved to a different region, so too does a literary scholar when moving, for example, from British Romanticism to Victorian Poetry. In order to know that one is there, one should already be there. Coming back to the "regions" of Jewish literature in modern European and American 
cultures, in comparing literary works in Russian and German, I was surprised to find - among other cultural dominants of these literary "regions" - that various Jewish writers and thinkers across political boarders exhibit an unusual fascination with allegory and its different varieties (Sobolev 2008 210-212). It was another surprise to find a concordant tendency in Rawet and Scliar; this essay will focus on its abalysis.

The second concordant problem, which usually looms at the background of the discussions of twentieth-century Jewish writers, is that of identity; correspondingly, it must also be addressed in a more explicit manner. "Identity?" one may ask, either raising one's brow or sighing resentfully, "Oh, identity, once again." Unfortunately, such a sigh occurs for a good reason: over the course of recent decades, "identity" has probably been the most used (and frequently misused) word in the study of Jewish diaspora literatures and of literary studies, in general. Literary and cultural scholars have repeatedly discussed national, religious and cultural identities; the unified and the hybridic; the singular and the collective; the subjectivized and the reified. There has also been an increasing awareness of the transformations one's identity undergoes in the processes of its textualizations and figurations. However, these are precisely the questions that I would like to skip over. Not because these questions are insignificant; they are important and can possibly become pivotal. Yet, what interests me here is not the question of the nature of identity, but rather the functions of the concept of "identity" in the discourse of Jewish literary studies. "Jewish identity" - or, in more nuanced wording, the preoccupation with the problem of Jewish identity - was frequently viewed as a core problem of Jewish cultural discourse (Boyarin 1996, Glenn and Sokoloff 2010), in general, and literary discourse, in particular (Bloom 1988, Budick 2001, Shaked 2006). Paraphrasing this position in terms of the above discussion, one may suggest that in a series of impressive and cogent works the problem of Jewish identity was interpreted as the pivotal cultural dominant of twentieth-century Jewish culture. Moreover, in many other studies, this problem of identity has been viewed as a "shibboleth," a defining mark whose palpable presence indicates that a given writer belongs to Jewish literature, and whose absence implies that he or she does not. As it seems, it is primarily on the basis of this criterion that Kafka was unusually allowed in, whereas Proust or Gertrude Stein were habitually kept out. In practical terms, the interpretation of the problem of identity as such a defining mark, in turn, implies that the discussion of a given literary text as a part of Jewish culture is frequently 
narrowed down and sometimes limited to the discussion of its representations of Jewish identities in either literal or metaphorical forms.

Without denying the centrality of the problem of identity for Jewish culture in the United States and for a relatively long period of time in Israel, I nevertheless would like to consider the possibility that in different cultural contexts it may not be equally central or equally applicable as an ultimate analytical category. At a more empirical level, this entails the necessity of better understanding the positions of Jewish writers towards the problem of identity beyond the North American context; with reference to Rawet and Scliar, such an analysis will be carried out in the second part of this essay. At a more theoretical level, I would like to probe the possibility of transcending the problem of identity, by suspending the assumption that seems to usually underlie its discussion. This is the assumption that, whatever the modalities of its textualizion and figuration may be, identity, as such, is unavoidably literal. As this not always self-conscious reasoning goes, after all one is doomed to have an identity, however complex, dynamic and contradictory this identity may be. One's identity can be culturally constructed but, even in this case, it must be literally "here". Moreover, in a world that is increasingly perceived as virtual and cross-referential, this literal identity is frequently considered as the ultimate referent of any figurations of subjectivity. Nevertheless, significantly, the same logic can also work in the opposite direction. Contemplating the possibilities of transcending this assumption of identity as an ultimately literal referent, one encounters a possibility of its being not only constructed or hybridic, but figurative in itself. This possibility, however, seems to require more detailed explanations.

As is usually said, "figurative" implies one thing "standing for" something else. Yet how can identity "stand for" anything? In more technically-oriented terms, the answer is relatively clear: the textual representations that literally refer to the question of identity may figuratively refer to other, possibly even more fundamental, problems beyond it. However, which problems could be more fundamental than the problem of "who am I"? This question evidently has farreaching implications. Among others, on a more collective level, this is a question of whether contemporary identity politics has an object that is, in itself, literal, figurative or both. Intuitively, we are familiar with a number of possible and questionable answers to this question of "who am I?": how I live and what I choose as the right thing to do; how the world around us presents itself 
to me; what I know and what I do not know; what I see and what I do not see; how other people react to me; and what degree of responsibility I am prepared to take for them. From a more conventional perspective, all these may be components of identity, whereas focusing on one of them would become a synecdoche representing identity as a whole. However, one may want to have a look at this problem from an opposite perspective. The representation of identity may be a figura standing for our position in regard to this broad and complex range of ontological, epistemological, intersubjective and political questions. From this point of view, the problem of identity becomes the most interesting and rich in cognitive implications precisely in those cases when it is explored against the question of the aspects and layers of human existence that its scrutiny discloses.

One may paraphrase this as follows: the question of identity, including Jewish identity, seems to assume one of its most significant forms when identity is treated as a figure for existence and choice, one's understanding and possible knowledge. In this case, the textual realizations of the question "who am I?" may entail its figuration as a broad range of other questions - for example, as in some of Rawet's texts discussed below, the question: 'What can I know about myself, others, and the world we live in?' In this case, however, as well as other concordant cases, identity is, strictly speaking, not something one may actually have. It is figuratively open, rather than literally closed; and, as such, it cannot be reified as an object that can be possessed. It is as such openness to further philosophical inquiry and literary figuration that this problem seems to be articulated throughout the twentieth-century Jewish diaspora literature, as opposed to a considerable part of modern Hebrew literature. Samuel Rawet and Moacyr Scliar gave this openness some of its richest and most memorable expressions. Furthermore, as will be shown below, the development of their writing exemplifies the transition from the assumption of the literariness of "identity" to its figuration, when the discourse of identity is understood as a language through which we, as human beings, confront and transform ourselves. Correspondingly, I would like to probe their writing with an eye on these figurative meanings of identity in their relation to broader philosophical questions and problems. As it seems, this approach allows for transcending the relatively narrow limits of the questions of identity politics without denying the textual significance of this problem, as such. 
As one cannot accomplish too many things in a single essay, I will briefly address the works of the pioneer of Brazilian Jewish literature, Samuel Rawet, and then turn to Scliar's Centaur for a more detailed examination. Rawet's earlier writings, however artistically impressive, seem to belong to a familiar tradition of Jewish diaspora writing. They focus on the painful Jewish experiences and torn consciousness within an essentially different and frequently unfriendly culture, as well as the discontinuities and clashes between the dominant and minority cultures. An immediately impressive and frequently anthologized story, "The Prophet", from the collection "The Tales of the Immigrant" articulates the experiences of a Holocaust survivor, who arrives to his relatives in Brazil. Literally speechless, alienated, surrounded by prejudice, misunderstanding and derision, he belongs to a world that has been irrevocably lost. "In the midst of all that," writes Rawet, "solitude weighed him down, the spiritual state that had not found any affinity whatsoever... He realized that any kind of affinity was impossible since their experiences were totally opposite" (Rawet 1998 7). He is "in exile," and this is an exile from which one cannot return. "The Prophet" is by no means an isolated example. In different forms, this figure of an alienated and "homeless" "wanderer," "aimlessly roaming the streets of Rio" (Kohl Bines 2010 217-235, 224), as well as the entire field of representations associated with it (such as loss and cultural non-belonging), echo and reverberate through many of Rawet's stories (Vieira 1995 51-99, Kohl Bines 2010 217-235). Furthermore, in his early works, the engagement with Jewish and anti-Semitic themes is not limited to different restatements of this tragic image of the postHolocaust survivor or the contemplation of its implications. Thus, "Christmas without Christ," published a little later and probably more nuanced as a story, evokes a less pronounced and more refined version of prejudices, where the main clichés of anti-Semitic rhetoric are dissimulated by their "liberal" presentation.

In Rawet's later writings, however, the contextual meanings of these representations, as well as their literary functions, undergo an essential change. It has been suggested that this change has much to do with a number of biographical factors and circumstances. In his earlier period, the self-identification with Jewishness, if not necessarily Judaism, was crucial for Rawet not only as a writer, but also as a person. To many, this centrality even seemed exaggerated. $\mathrm{He}$ also spent a period of time in Israel, where he assisted Niemeyer in the construction of the first core buildings of the University of Haifa (Vieira 1995 56, Kohl Bines 2010 235); it is in one of 
these buildings, the Eshkol Tower, that I am writing this essay. Later Rawet's attitude towards, so to speak, "empirical Jewry" radically changes, and he finds himself increasingly alienated from the Brazilian Jewish milieu of his time and, as it seems, Jewish culture in general. This causal biographical explanation, however important, does not diminish the significance of the more intrinsic literary dimension of the problem. In this period, the themes of alienation and irrevocable exile, while remaining the focus of Rawet's writings, are increasingly represented and interpreted as the existential condition of the human being qua human being. After his death in 1984, he was called "the inventor of the exile" by the Brazilian-Jewish writer and journalist Alberto Dines (Vieira 1995 61, Vieira 2009 xi). At the same time, this literary, ontological and hermeneutic change is probably related to Rawet's growing self-isolation as a person, and a radical change in those questions he was asking about himself and his writing.

What seems to interest him in these later stories is the very life of consciousness, not only its loneliness and alienation, but its instability, volatility, the indeterminacy of meanings, and its various modes of temporality. Thus, in "The Seven Dreams," reality discloses itself as a sequence of dreamy episodes, only tangentially related to one another, shown in reverse order. "The First Cup of Coffee" foregrounds the indeterminate and volatile character of human existence; in "Faith in One's Craft," Rawet probes the very experience of literary writing as it tries to find its way through this existential indeterminacy. The endings of his later texts - many of which can be called stories only if one overstretches the concept - become more and more open and indeterminate, frequently bringing the reader back to their beginning, though at a different level of understanding. Not that the themes and metaphors of "wandering" and "homelessness" completely disappear from these stories. As Rosana Kohl Bines points out, he "moves his characters through endless peregrinations and ruminations in often urban and nocturnal spaces, where the cosmopolitan, anonymous travelers confront... inhospitable and impersonal settings" (Kohl Bines 2010 222). Although these "wanderings" may be more manifest in Rawet's early stories, this also holds true for several later texts. At the same time, the interest in the realistic, psychological, intersubjective or social meanings of the wanderings of their protagonists is gradually replaced by that in their reflection in the workings of consciousness. At times, this change may be directly thematized; thus, in "Lisbon by Night" Rawet writes: "The time when he 
used to ask infinite number of questions about numerous possibilities of who might be by his side, had passed" (Rawet 1998 80).

By the same token, in these later texts Jewish themes do not disappear completely. Thus, in "Lisbon by Night" the Jewish protagonist by chance confronts a Nazi criminal in a night bar. "I hate you, Isaac," cries the suddenly frightened Nazi, "I hate the Jews! They're after me! ... I hate all of you people, and you people have finally located me" (Rawet 1998 85). Nevertheless, as it seems, overwhelmed by his helplessness in the face of the world and incapable of overcoming his self-isolation, the protagonist lets the Nazi disappear without being identified and brought to justice. In assessing this highly ambivalent and disquieting ending, one may think for a moment that this is just a restatement of the themes and perceptions central to "The Prophet"; under close scrutiny, however, it becomes clear that this is not the case. Whatever their thematic similarity to Rawet's earlier stories may be, from a more formally-oriented point of view these later texts present an almost complete reversal. In the earlier stories, alienation and exile were used as predicates that enable the articulation of Jewish (or, on a broader scale, an outsider's) experience in an alien and hostile world; these were the predicates of alienated identity. In contrast, it is on the life of the essentially lonely consciousness - as it is repeatedly engaged in attempts to contemplate its place in the world, its functioning, its own authenticity and self-delusions - that Rawet's later texts focus. In these attempts, references to Jewishness may be present or not; when they are present, however, they are no longer the stories' referents in themselves. In these later stories "Jewish" predicates appear as figures for alienation and exile, indeterminacy and temporality, the painful and disjointed consciousness.

A similar dialectics and development are even more pronounced in the works of Moacyr Scliar. As in the case of Rawet, placing his work in a diachronic perspective can serve synchronic purposes as well; it is against this developmental difference that some of the major literary elements of Scliar's mature work become especially palpable. His early novella (or short novel), The War in Bom Fim, focuses on mundane Jewish life in Porto Alegre, in the Bom Fim neighborhood "settled by Russian Jews" (Vieira 1995 152). Scliar describes its hopes and fears, the everyday and the fantastic, the humorous and the painful, the growing gender awareness and class tensions, imaginary victories and quite real humiliations, the condition of being torn between two cultural worlds - the Jewish and the Brazilian. The story is perceived through the 
eyes of an adolescent; yet this small adolescent world, seemingly devoid of major events, constantly mimics and reenacts much larger worlds: the adult social world of Porto Alegre and an even larger historical world of the Second World War with its heroism and unimaginable horrors. Thus, as the narrative develops against the background of the news from the far fronts of the great war and the recurrent echoes of Nazi propaganda, its characters perform a series of - as Kenneth Burke would say - "symbolic acts" that aim to take a stance in the World War through their partly real, partly imaginary actions within the immediate geographical and social milieu.

The same holds true on a broader scale. Throughout the novella, this iconicity of the everyday is performed through play and imitation, dream and desire, exaggeration and understatement, carnival and fighting. Given this focus on the mundane, as the latter reflects and reenacts the historical, it is anything but surprising that the search for an answer to the question 'who am I amidst all this, and how should I act, accordingly?' - in other words, the question of identity - is explicitly central to the entire narrative. At the same time, two crucial features already separate this novella from more traditional and straightforward identity narratives in the style of the Yiddish literature of the beginning of the twentieth century. First, this is a hybrid rather than essentialist identity; as Vieira writes, "Despite the strong ethnic presence, the novella also undermines the notion of cultural absolutes with its gallery of Jews and non-Jews, blacks and Germans" (Vieira 2009 lxi). Second, this hybridic and unstable identity, as it seems, cannot be directly contemplated; it is rather repeatedly enacted and dramatized in a series of symbolic acts, partly misguided, partly imaginary, some of them with catastrophic consequences. These are the allegories of identity with all its complexity, ambivalence, and hybridity.

This relation between identity and allegory is reversed in the much later and critically acclaimed The Centaur in the Garden; in this later book this reversal is further complicated by Scliar's ubiquitous irony and the ambivalent role the fantastic plays in the novel. This is an "autobiographic" story told by "a Jewish centaur": half-man, half-horse, born to the Jewish farmers who had earlier been resettled to Brazil from one of the crowded shtetls in the Western parts of the Russian Empire (Scliar 2011 7-37). The birth of this centaur, named Guedali, is explicitly related to the new natural and cultural conditions and, more specifically, to the appearance of a winged horse circling in the air above these new lands. The family is frightened, at first, but after a while accepts the child as he is, whereas in a series of highly suggestive 
episodes the protagonist examines the non-human capacities of his body with a mixture of distaste, pain and fascination. The same holds true for the family's attitude towards their new existential milieu. If, at first, Guedali's mother is frightened by "the Indians" (Scliar 2011 14-15), who might be somewhere in the vicinity, later the centaur Guedali makes a failed attempt to befriend a Native American boy (Scliar 2011 29-30). Eventually, as the story develops, the main character manages to rid himself of the horse part of his body, through complex and costly surgery, and to hide his front legs in cowboy boots. From a more formal point of view, the novel's combines several major genre traditions. First, it is written as a highly ironic version of the Bildungsroman; second, this is a modern picaresque novel, exhibiting many details and plot twists characteristic of the latter. Third, the novel can be easily catalogued as an example of South American "magic realism." This genre tension and the resultant indeterminacy is important not only in itself; the novel's formal indeterminacy iconically reenacts a series of thematic indeterminacies, which emerge throughout the novel.

At first sight, if there has ever been an ultimate symbol for the cultural hybridity of the Jews in the diaspora in modern times, it is this: the "Jewish centaur." This strange entity visually represents that "double condition of being," of which Scliar spoke to Nelson H. Vieira in an interview (Vieira 2009 lxxxvi). An epigraph from Joseph Heller ("Since when do Jews ride horses?") already brings this doubleness to the fore; indeed, the shtetl Jews are not supposed to ride horses, but the protagonist is no longer a Jew from the traditional East European Jewish world. Correspondingly, when the novel is read along these lines, both the mixed feelings of the protagonist towards himself and the surgery that aims to disavow his initial nature, seem to stand for different dimensions of the processes of assimilation and cultural adaptation. Thus, for example, in diverse literature on modern Jewish self-consciousness, as well as anti-Semitism, much has been written on the obsession with "Jewish bodies" (for example, Gilman 1991, Gilman 2003) and the presumably unchangeable "Jewish outlook." More than a few Central European Jewish intellectuals complained about their misleading Jewish appearance, insisting that their "spirit" is entirely German. Others, however, praised this mythic Jewish appearance as a sign of critical intellect and inexhaustible energy. In contrast to both, anti-Semites of different persuasions have obsessively focused on Jewish bodies in the hopes that this would provide a possibility of distinguishing between those who are truly European from those who only pose as 
such. A comparable series of complex and ambivalent attitudes towards the protagonist's body is evident throughout the novel. "I become painfully aware of my shanks, my hooves," complains Guedali, "I am obliged to think of something called horseshoes" (Scliar 2011 24). In the novel, there are literally hundreds of similar experiences - some of them passing, others deep and significant - when Guedali obsessively examines his body. Yet, in the paragraph quoted above he also continues: "I become conscious of my thick, beautiful tail, of my enormous penis with its circumcision mark" (Scliar 2011 24). As the text shows again and again, Guedali's attitude towards his hybrid body is deeply ambivalent, as well as his attitude towards his "hybridity," in general. Arguably, in the last two centuries a comparable ambivalence has been a much more characteristic Jewish attitude towards Jewishness than simple self-hatred in the style of Otto Weininger.

Were this the whole picture, one would have to conclude that the figure of the centaur is used in the novel to designate the hybridic Jewish identity in modern Western countries, as well as to problematize this identity, its self-consciousness and its self-representations. In this case, Scliar's novel would probably belong with the texts of Philip Roth and the films of Woody Allen. Without a doubt, this hermetic possibility is clearly suggested by the novel; nevertheless, it is also explicitly denied, as several crucial elements of the novel resist this interpretation. Paradoxically enough, as in Scliar the figuration of a hybrid identity achieves its apotheosis, the actual textual representations of the figure of the centaur are such that they resist its effacement by the problems it represents. To begin with, one should note that, at a logical level, being Jewish and being Brazilian are relatively symmetrical categories. In contrast, there is radical asymmetry in the figure of hybridity in the novel; the two parts forming the Jewish centaur belong to different levels of taxonomy: a genus is combined with a species, a horse with a Jewish child born in the countryside to a family of Russian-Jewish settlers. Already at this level, the textualizations of the figure of hybridity resist its absorption to the discourse of Jewish identity in the diaspora, for which it seemingly stands. Moreover, this is only one feature among several others that make this reversed literalization of the allegorical figure impossible.

As is known, usually it is their Jewishness that assimilated Jews tend to perceive as a burden; many German-Jewish, Russian-Jewish or North American-Jewish writers may serve as examples. In contrast, it is his horse body, as opposed to the consciousness of the Jewish child or 
adolescent, which Guedali perceives as an unbearable burden that he dreams of being rid. As regards Jewish cultural consciousness, surprisingly enough, in the novel it is usually underscored and even praised, and little ambivalence towards it is shown by the narrative. The novel repeatedly mentions Jewish religious and literary texts, discusses Jewish thought and history, pogroms in Ukraine and Baron Hirsh's project of Jewish resettlement to South America. Guedali studies the Bible and the Talmud, explores Jewish history, reads not only Marx and Freud, but also stories by Sholem Aleichem, he dreams about going to Israel (Scliar 2011 40-45). As a distant echo from the shtetl and post-shtetl literature, as well as Chagall's shtetl iconography, this Jewish centaur-child even learns to play the violin (Scliar 2011 27-8). Furthermore, in spite of a much more complicated, darker and ambivalent historical picture (Lesser 1995, Vieira 1995 915), descriptions and expressions of anti-Semitism are almost absent from Scliar's narrative. On the contrary, it is Guedali's Jewish family that exhibits a deep racial prejudice and, for a long period of time, rejects Guedali's bride and later his wife, Tita, as a "goy" (Scliar 2011 94-137). “'She's not one of us,' Mama would say to me when we were alone. 'I'll never get accustomed to her"' (Scliar 2011 94-137). Even the fact that Tita belongs to a much higher social stratum than Guedali's family is not enough to make his family accept her as Guedali's wife. In contrast, Tita's family and household members happily embrace him. The main problem with these recurrent references to and representations of Jewish culture is not that Guedali's attitude towards them is ambivalent, but rather that they do not address his main question: that of being a Jewish centaur (Scliar 2011 44). To put another way, from the "Jewish" side of the Jewish consciousness / horse body figurative rift, one finds the absence of representational ambivalence, where in referential historical terms it is supposed to be present.

The third problem is closely associated with the second. As the notion of cultural hybridity usually refers to the divided cultural consciousness, it is also worth noting that in the novel the border within this hybridic creature roughly corresponds to the border between the consciousness and the body. Furthermore, as already mentioned, in a series of telling episodes the protagonist examines his horse body as a disgusting and fascinating object that is external to him. Correspondingly, in the process of assimilating to the surrounding world, as it is described in the novel, it is this "external" horse-body that is repeatedly foregrounded and examined, and that is eventually lost, whereas the protagonist's consciousness with all its Jewish references and self- 
references is retained. At the same time, paradoxically, it is with this horse body - of which he dreams of ridding himself - that Guedali repeatedly associates the freedom he loses after his assimilation to the safe, yet colorless and highly predictable middle-class existence within a predominantly Jewish milieu. As a centaur, Guedali could freely run through fields and the wilderness - better and quicker than any human being; it is as a centaur that he attempted to befriend a Native American boy; it is as a centaur that he worked in a circus and underwent unforgettable and sexually intense experiences (Scliar 2011 57-66). By the same token, it is to this centaur body that Guedali attempts to return through a second surgery, later on in the novel (Scliar 2011 157-178). To put it another way, it is the animal body that is problematic and whose meaning is ambivalent, that repulses and attracts him - not cultural consciousness, whether Jewish or not.

Finally, in assessing the possibility of interpreting the figure of centaur as an allegory for the hybridic Jewish consciousness in diaspora, one must remember that, from the Jewish-side of this supposed allegory of cultural hybridity, its figuration is complicated by numerous explicit and literal references to a broad range of components of Jewish culture and traditional existence. As already mentioned, the problem of Jewish identity is repeatedly and variously addressed in the novel in a direct non-figurative manner, and these direct narrative representations show little ambivalence towards Jewish history, culture or identity. Significantly, these non-figurative and non-ambivalent references to Jewish tradition and culture are present at the same narrative level as and alongside the Jew/horse dichotomy. In other words, the figure of the centaur and its referents exist and interact within the very same narrative space, thus destabilizing the possibility of dichotomizing the allegorical sign and its referent. In addition, the final chapter of the novel calls into question the reality of the story of the centaur, his transformations, his gains and losses, his longings and nostalgia (Scliar 2011 198-216). This ending foregrounds, once again, the question of the meaning beyond the figure of the centaur as the central question of the novel. This is the same question of "who am I?," and it is explicitly left open. There is no indication that "Jewish cultural hybridity in the diaspora" may count as the answer, even though, as is clearly and non-allegorically shown throughout the narrative, this is a significant part of the answer.

It is little wonder, therefore, that endlessly pondering upon the question of who he is, examining literature, mythology and philosophy, Guedali looks for centaurs rather than their 
components, whether human or animalistic. "Psychoanalysis, dialectic materialism, nothing; laws of supply and demand, nothing, nothing; fiction, nothing. Nothing seemed applicable to my case. I was a centaur, irremediably a centaur" (Scliar 2011 44). In other words, it is this very figure of hybridity that is experienced by him as identity, rather than any of its components - physiological or cultural, Jewish or non-Jewish, separately or together. This accent placed on the very form of hybridity, rather than the supposedly essnetial or cultural contents contained by it, also resists the interpretation of the story as an allegory of assimilation and its identity problems. In addition, although, as has already been said, The Centaur in the Garden contains numerous features of the Bildungsroman, most of these features are ironically and playfully subverted. From the very beginning, the above quoted epigraph from Joseph Heller foregrounds this ironic detachment from what in The War in Bom Fim was still the tragic core of the story. In this sense, Rawet and Scliar explored the related, albeit counter-oriented implications of allegory as a figurative mode. In more theoretically-oriented discussions of the problem, these implications were famously articulated in Walter Benjamin's book on tragic drama (Benjamin 1977) and Paul de Man's essay on the temporality of human existence (De Man 1983). In contrast to Benjamin's and Rawet's association of allegory with melancholy, in Scliar, as in de Man, allegory is closely associated with irony and elements of the grotesque. This choice of ironic mode further problematizes the interpretation of the central figure of the novel as that of Jewish cultural hybridity with all its historically tragic implications and echoes.

In sum, multiple discrepancies between the actual textualizations of Scliar's allegory and its suggested referent, the accent placed on the figure itself as a living character, the ironic narrative presentation of this figure, as well as a broad range of literal references to the supposed signified of this allegorical figure, prevent the closure of its interpretation within the familiar repertoire of Jewish identity questions. On the contrary, instead of allegorically designating a given cultural identity, and in spite of his identity problems, Scliar's representation and narrativization of the figure of the centaur indicates a broad range of diverse questions: those of consciousness and the body, freedom and convention, the wilderness and the city, danger and safety, being one and being multiple, being able and being unable to belong. In his novel, as probably outside it, it is for these meanings that the allegory of "identity" stands. Identity, and by implication Jewish identity, is no longer perceived as essentialist closeness, but rather as a figure of openness; as 
Scliar himself says in the interview quoted above, "Judaism is going to always be a reason for being different" (Vieira 2009 lxxxviii).

In conclusion, placing the above discussion within a comparative perspective may shed further light on its contextual meaning. However unique and impressive Rawet's and Scliar's literary achievements are, they also seem to belong with the much broader developments in twentieth-century Jewish literature. In examining Jewish literature written in different languages over the course of the twentieth century, one gradually comes to the conclusion that one of its most intriguing and complex questions is the problem of identity precisely when it transcends its literal meaning. One speaks of cases in which the question of Jewish identity is still textually central, and moreover may retain many of its earlier predicates; yet the actual textualizations of this question become increasingly contingent on broader thematic, epistemological and political problems. The identity question is consistently referred to by the texts in its most literary form; nevertheless, the significance of these references is disclosed only through a chain of their figurative transformations, as they are carried out or suggested by the texts. In empirical terms, the range of these referents of the figurative textualizations of the questions of identity may range from the most basic ontological and epistemological problems to the most immediate social and political ones. It is in this sense that the question of identity becomes essentially allegorical, even though this allegory tends to sustain its figurative openness. Kafka, as probably one of the ultimate examples of twentieth-century Jewish writing in European languages, may serve an example of this dialectics (Sobolev 2013). Indeed, despite "Jewish" attributes associated with his characters, these attributes are significant not only in themselves, but first and foremost because they make it possible for Kafka to lay bare some of the most significant aspects of human existence in the modern world. It is indeed true that alienated and inconsistent identity is one of the main elements of his narratives; yet the significance of this element can be understood only when it is examined as a ground for both knowledge and self-delusion, as well as a prism through which the world is disclosed.

A historical perspective may add a further dimension to this comparative contextualization. The classical Yiddish writers of the late nineteenth century - like Sholem Aleichem, Mendele Moykher Sforim and Y. L. Perez - wrote against the background of a large and densely populated Yiddish-speaking world. As almost all the Brazilian Jewish writers were born either in 
the Western parts of the Russian Empire and Poland, or in Brazil to the families of JewishRussian immigrants, it is little wonder that most of them make repeated references to this Yiddish literary tradition. At the same time, for them this world was already irrevocably lost - both geographically and historically. Correspondingly, the question of identity had to be defined and construed anew in the absence of the cultural world that constituted an immanent part of its definition. Similar processes took part in what is probably the closest relative of Brazilian Jewish literature - in Russian Jewish literature after the Second World War. Moreover, as time went on, in the writings of the Russian Jews the question of identity was increasingly allegorized, mostly as a figure for the questions of ontology and politics (Sobolev 2014). Following a comparable path from the literal to the figurative, in Rawet and Scliar the question of identity opens up towards the problems of epistemology and psychology. Without a doubt, in its literal sense this question still remains textually central for both writers, as it probably is for most of twentieth century Jewish literature. By the same token, the textualizations of identity in the writings of Rawet and Scliar retain a substantial number of attributes associated with Jewish identity in both earlier texts and the broader cultural imagination. Furthermore, these representations acquire the elements of ambivalence and hybridity, usually associated with the representation of Jewishness in diaspora literature. At the same time, one of the most notable, impressive and intriguing elements of these texts is their attempt to transcend these representations towards the broad range of questions discussed above - questions that one may find difficult to reformulate in strictly literal terms, let alone answer. 


\section{Referências}

Anderson, Benedict Richard O'Gorman. Imagined communities: Reflections on the Origin and Spread of Nationalism. London: Verso, 1991.

Benjamin, Walter. The Origin of German Tragic Drama. London: NLB, 1977.

Biale, David, Ed. Cultures of the Jews: A New History. New York: Schocken Books, 2002.

Bloom, Harold. "Jewish Culture and Jewish Identity." In Harold Bloom. The Poetics of Influence: New and Selected Criticism. Ed. John Hollander. New Haven: Henry R. Schwab, 1988.

Boyarin, Jonathan. Thinking in Jewish. Chicago and London: The University of Chicago Press, 1996.

Budick, Emily Miller, Ed. Ideology and Jewish identity in Israeli and American Literature. Albany: State University of New York Press, 2001.

Casanova, Pascale. The World Republic of Letters. Cambridge, Mass., London: Harvard University Press, 2004.

De Man, Paul. "The Rhetoric of Temporality." In Paul de Man. Blindness and Insignt: Essays in the Rhetoric of Contemporary Criticism. 2nd. ed. Minneapolis: University of Minnesota Press, 1983, 187-228.

Feierstein, Liliana Ruth. "The New Midrash: The Jewish Press in Argentina." In Susanne Marten-Finnis and Michael Nagel, Eds. The PRESSA. International Press Exhibition Cologne 1928 and the Jewish Contribution to Modern Journalism, V.2. Bremen: edition lumière, 2012, 559-590.

Gilman, Sander L. The Jew's Body. New York: Routledge, 1991.

Gilman, Sander L. Jewish Frontiers: Essays on Bodies, Histories, and Identities. New York: Palgrave Macmillan, 2003.

Glenn, Susan A. and Sokoloff, Naomi B. Boundaries of Jewish Identity. Seattle and London: University of Washington Press, 2010.

Goldmann, Lucien. The Hidden God: A Study of Tragic Vision in the Pensees of Pascal and the Tragedies of Racine. London: Routledge \& Kegan Paul, 1964. 
Harshav, Benjamin. The Polyphony of Jewish Culture. Stanford, Calif.: Stamford University Press, 2007.

Kohl Bines, Rosana. "Samuel Rawet's Wandering Jew: Jewish-Brazilian Monologues of Home and Displacement." In Jewish Cultural Studies, V.2: Jews at Home: The Domestication of Identity. Ed. Simon J Bronner Oxford, Portland, Or.: The Littman Library of Jewish Civilization, 2010, 217-240.

Lesser, Jeffrey. Welcoming the Undesirables: Brazil and the Jewish Question. Berkley, Los Angeles, London: University of California Press, 1995.

Miron, Dan. From Continuity to Contiguity: Toward a New Jewish Literary Thinking. Stanford, Calif.: Stamford University Press, 2010.

Rawet, Samuel. The Prophet and Other Stories. Albuquerque: University of New Mexico Press, 1998.

Shaked, Gershon. Zehut: Sifruyot Yehudiyot Bilshonot Laaz (Identity: Jewish Literatures in European Languages). Haifa: The University of Haifa Press, 2006 (In Hebrew).

Scliar, Moacyr. The Centaur in the Garden. Lubbock, Texas: Texas Tech University Press, 2011.

Scliar, Moacyr. The War in Bom Fim. Lubbock, Texas: Texas Tech University Press, 2010.

Sobolev, Dennis. "Allegoria uMashmaut beYetsirat Kafka." In Kafka: Perspektivot hadashot. Eds. Ziva Shamir, Yohai Ataria and Haim Nagid. Tel-Aviv: Safra, Iyun uMekhkar, 2013, 24-67 (in Hebrew).

Sobolev, Dennis. Evrei i Evropa (The Jews and Europe). Moscow: Text, 2008 (in Russian).

Sobolev, Dennis. "Jewishness as Difference in the Late Soviet Period and the Work of the Strugatsky Brothers." In Studies in Jewish Literature and Culture in Multiple Languages. Eds. Hillel Weiss, Roman Katsman, and Ber Kotlerman, Newcastle: Cambridge Scholars, 2014, 585-611.

Vieira, Nelson H., "Introduction.” In Contemporary Jewish Writing in Brazil: An Anthology. Ed. Nelson H. Vieira. Lincoln and London: University of Nebraska Press, 2009, xv-lxxvi.

Vieira, Nelson H. Jewish Voices in Brazilian Literature: A Prophetic Discourse of Alterity. Gainesville, and others: University Press of Florida, 1995. 
Weiss, Hillel. "Around the Point." In Studies in Jewish Literature and Culture in Multiple Languages. Eds. Hillel Weiss, Roman Katsman, and Ber Kotlerman, Newcastle: Cambridge Scholars, 2014, 1-16.

Weiss, Hillel. Katsman, Roman and Kotlerman, Ber, Eds. Studies in Jewish Literature and Culture in Multiple Languages. Newcastle: Cambridge Scholars, 2014, 585-611.

Wisse, Ruth R. The Modern Jewish Canon: A Journey Through Language and Culture. New York, London, Toronto, Sydney, Singapore: The Free Press, 2000.

Wirth-Nesher, Hana. "Defining the Indefinable: What is Jewish Literature?" In Hana WirthNesher. What is Jewish Literature? Ed. Philadelphia, Jerusalem: The Jewish Publication Society, 1994. 